Contents List available at RAZI Publishing

Geological Behavior (GBR)

Journal Homepage: http://www.razipublishing.com/

journals/geological-behavior/

\title{
PREDICTION OF ROCK MASS PROPERTIES, TUNNEL STABILITY AND SUPPORT PRESSURE BY GEOLOGICAL STRENGTH INDEX (GSI) IN CROCKER FORMATION: A CASE STUDY
}

Lee Kiun You*, Ismail Abd Rahim

\author{
Geology Program, Faculty of Science and Natural Resources, Universiti Malaysia Sabah, Jalan UMS, 88400 Kota Kinabalu, Sabah. \\ *Corresponding Author E-mail: klkyou@outlook.com
}

This is an open access article distributed under the Creative Commons Attribution License, which permits unrestricted use, distribution, and reproduction in any medium, provided the original work is properly cited

\section{ARTICLE DETAILS}

\section{ARTICLE HISTORY:}

Received 12 May2017

Accepted 12 July 2017

Available online 10 September 2017

\section{Keywords:}

Geological Strength Index (GSI), tunnel, Crocker Formation, limit equilibrium analysis

\section{ABSTRACT}

\begin{abstract}
This study was conducted along a tunnel in Crocker Formation. The objectives of this study are to determine the value of Geological Strength Index (GSI) and to predict rock mass properties, very unfavourable discontinuities combination and tunnel support pressure for rock bolts or shotcrete for the tunnel. Engineering geological mapping, rock sampling and estimation of GSI values and the disturbance factor were conducted along the tunnel faces. Laboratory analysis includes Point load and dry density test and data analysis consists of kinematic analysis and limit equilibrium analysis. The rock mass was characterised by $94.88 \mathrm{MPa}$ UCS, $0.024 \mathrm{MN} / \mathrm{m}^{3}$ unit weight, widely space and high persistency of discontinuities. The GSI value is 50 with 0.8 disturbance factor. The cohesion, tensile strength and friction angle are $3.671 \mathrm{MPa}, 0.056 \mathrm{MPa}$ and $25.20^{\circ}$, respectively. There are eight possibilities of discontinuities combinations on tunnel roof that have factor of safety (F.O.S) lower than 2 and combination of joints 2, 4 and 6 has the highest maximum wedge volume of $28.37 \mathrm{~m}^{3}$. The maximum support pressure of rock bolts or shotcrete for F.O.S of 2 is $0.04 \mathrm{MN}$. The individual discontinuity plane has been identified to overestimate friction angle and cohesion values, then the GSI system should be applied in homogeneous or isotropic and not in structurally controlled rock masses.
\end{abstract}

\section{INTRODUCTION}

This study was conducted along a tunnel in Tenom, Sabah (Figure 1) as shown in figure 1a. The study area is underlain by the Crocker Formation of Late Eocene to Late Early Miocene ages and consists of tectonically disturbed thick amalgamated sandstone with thin shale layers (figure 1b) [1]. The objectives of this study are to determine the value of Geological Strength Index (GSI) and to predict the rock mass properties, very unfavourable discontinuities combination and tunnel support pressure for rock bolts or shotcrete for the tunnel in Crocker Formation.

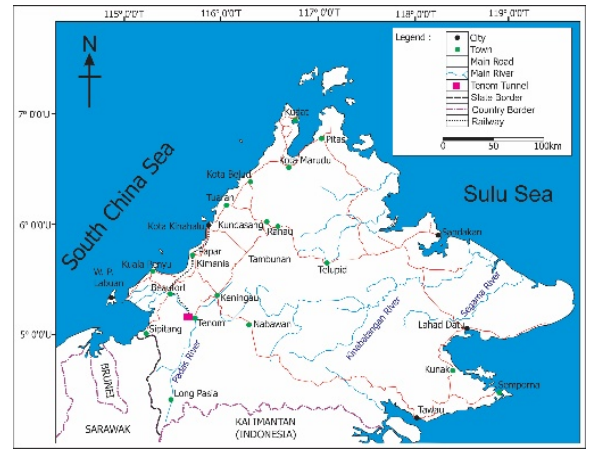

Figure 1: $\quad$ Location of Tenom Tunnel.

Geological Strength Index (GSI) was introduced by a researcher as an extension from Hoek-Brown criterion and evolved until but it was still for hard rock masses which generally equivalent to RMR [2-4]. GSI has been applied continuously in various major tunnel excavations around the world especially in heterogeneous rock masses such as flysch [5]. One of the major applications of this system was done by some researcher for a tunnel of Egnatia Highway in Northern Greece [6]. Another major application was done for the Chenani-Nashri Tunnel which is the longest road tunnel in India [7]. This study has been conducted in the study area because the application of GSI has never been attempted for the tunnel in Crocker Formation.

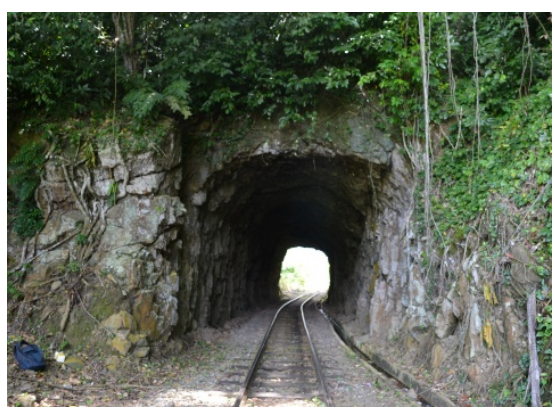

Figure 1a: Entrance of Tenom Tunnel. Photo direction - east southeast (ESE) to west northwest (WNW)

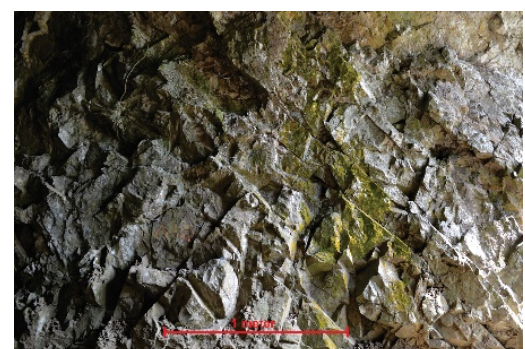

Figure 1b: Amalgamated thick sandstone unit of Crocker Formation. 


\section{METHODOLOGY}

Discontinuity survey was conducted to obtain quantitative description of discontinuities as well as rock sampling. GSI values were determined by using the charts by a researcher $[8,9]$. The disturbance factor was obtained by field observation on the tunnel face [10]. Laboratory study was done to determine the Uniaxial Compressive Strength (UCS) via point load test with a conversion factor of 22 and unit weight via dry density test $[11,12]$. The final UCS, Hoek-Brown material constant and dry density values of intact rock were obtained via weighted average method [5]. Hoek-Brown material constant $\left(\mathrm{m}_{\mathrm{i}}\right)$ for sandstone is 17 as suggested values [13]

Rock mass properties of the tunnel were determined using RocLab software where the input parameters are UCS of intact rock, GSI value, disturbance factor, and Hoek-Brown material constant [14]. RocLab uses the Hoek-Brown and Mohr-Coulomb criteria to empirically estimate the rock mass properties (cohesion, friction angle and tensile strength of rock mass) based on the given parameters [10]. Result of rock mass properties were then used as input parameters into Unwedge software to determine the very unfavourable discontinuities combinations [15]. Wedge failure is the most potential failure based on kinematic analysis and limit equilibrium analysis. The calculations done by the software were based on the Block Theory [16]. Support pressure required for tunnel support by using rock bolts or shotcrete was calculated based on design factor of safety of 2 which is sufficient to avoid failure caused by the vibrations from passing train.

\section{RESULTS AND DISCUSSION}

The GSI value from field observation for the study area is 50 after being reduced from 55 as suggested by a researcher because the tunnel consists of thick amalgamated sandstone with thin shale layers instead of thick amalgamated sandstone with thin siltstone layers (Figure 2) [17]. This value was obtained by identifying the surface condition and the type of the tunnel wall [18]. Based on this study, the surface condition of the tunne wall is good with structure and composition of type III. The tunnel geometry and discontinuity orientation were shown in Table 1 . Table 2 shows the result of laboratory testing, parameters and derived rock mass properties from related schemes and software. The disturbance factor was chosen as 0.8 because blasting and hammering were used in the excavation method [10]. Friction angle was reduced by $5^{\circ}$ due to shear strength of bedding plane.

The result of limit equilibrium analysis via Unwedge was presented in Table 4 [15]. There are eight out of the twenty possible discontinuities combinations on tunnel roof that have F.O.S lower than 2 with a maximum wedge volume of $28.37 \mathrm{~m}^{3}$ formed from combinations of joint 2,4 and 6 (Figure 3). The wedges were formed by the combination of at least 3 discontinuities. The F.O.S value for roof wedges was nil because the wedge was practically hanging without support and might have failed immediately after excavation. The wedge blocks at the crown might have failed over the years and altering their shape. The overestimation of friction angle and cohesion for individual discontinuity plane has been causing high values of F.O.S for left and right wall of the tunnel. This might be caused by the rock mass properties obtained from GSI system do not represent individual discontinuity plane but the rock mass as a whole, where the GS is only suitable for isotropic or homogenous rather than structurally controlled rock masses [19]. To achieve F.O.S of 2, rock bolts or shotcrete can be installed on to the tunnel roof with maximum support pressure of $0.04 \mathrm{MN}$.

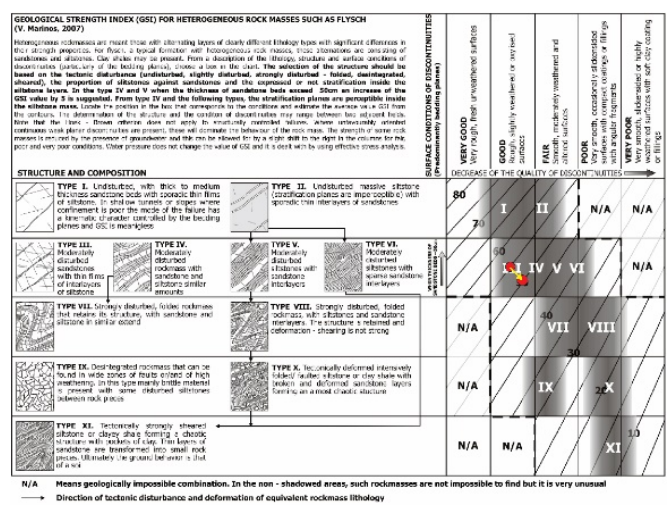

Figure 2: $\quad$ GSI chart (Marinos, 2007) and value for rock mass (red dot).

Table 1: Tunnel geometry and discontinuity orientation.

\begin{tabular}{|l|l|l|l|}
\hline Tunnel & Values & Discontinuity & Strike/Dip \\
\hline Length & $42.69 \mathrm{~m}$ & Joint 1, J1 & $30 / 60$ \\
\hline Width & $4.4 \mathrm{~m}$ & Joint 2, J2 & $185 / 55$ \\
\hline Height & $4.6 \mathrm{~m}$ & Joint 3, J3 & $215 / 70$ \\
\hline Right wall & $87^{\circ}$ & Joint 4, J4 & $87 / 42$ \\
\hline Left wall & $87^{\circ}$ & Joint 5, J5 & $2 / 24$ \\
\hline \multirow{2}{*}{} & \multirow{2}{*}{ Joint 6, J6 } & $277 / 86$ \\
\cline { 2 - 4 }
\end{tabular}

Table 2: Parameters and rock mass properties.

\begin{tabular}{|l|l|}
\hline Parameters / Properties & Values \\
\hline GSI & 50 \\
\hline Disturbance factor & 0.8 \\
\hline Unit Weight $\left(\mathrm{MN} / \mathrm{m}^{3}\right)$ & 0.024 \\
\hline Hoek-Brown material constant $\left(\mathrm{m}_{\mathrm{i}}\right)$ & 17 \\
\hline UCS $(\mathrm{MPa})$ & 94.88 \\
\hline Cohesion $(\mathrm{MPa})$ & 3.67 \\
\hline Friction angle for bedding $\left(^{\circ}\right)$ & 20.2 \\
\hline Friction angle for joint $\left(^{\circ}\right)$ & 25.2 \\
\hline Tensile strength $(\mathrm{MPa})$ & 0.056 \\
\hline
\end{tabular}

Table 4: Predicted discontinuities combinations which contain F.O.S below 2 including maximum support pressure needed and maximum wedge volume.

\begin{tabular}{|c|c|c|c|c|}
\hline Combination & $\begin{array}{l}\text { Type of } \\
\text { wedges }\end{array}$ & F.O.S & $\begin{array}{l}\text { Max. } \\
\text { support } \\
\text { pressure } \\
(\mathrm{MN})\end{array}$ & $\begin{array}{l}\text { Max. } \\
\text { wedge } \\
\text { volume } \\
\left(\mathrm{m}^{3}\right)\end{array}$ \\
\hline \multirow{4}{*}{ J1,J2,J6 } & Floor & Stable & 0.00 & 2.071 \\
\hline & Left & 1183.134 & 0.00 & 0.227 \\
\hline & Right & 3024.801 & 0.00 & 0.227 \\
\hline & Roof & 0.000 & 0.02 & 2.071 \\
\hline \multirow{4}{*}{$\mathrm{J} 1, \mathrm{~J} 2, \mathrm{~J} 3$} & Floor & Stable & 0.00 & 0.092 \\
\hline & Left & 6780.508 & 0.00 & 1.944 \\
\hline & Right & 1196.101 & 0.00 & 1.944 \\
\hline & Roof & 0.000 & 0.01 & 0.092 \\
\hline \multirow{4}{*}{ J1,J2,J5 } & Floor & Stable & 0.00 & 0.011 \\
\hline & Left & 812.480 & 0.00 & 18.362 \\
\hline & Right & 1231.028 & 0.00 & 18.362 \\
\hline & Roof & 0.000 & 0.00 & 0.011 \\
\hline \multirow{4}{*}{$\mathrm{J} 1, \mathrm{~J} 3, \mathrm{~J} 4$} & Floor & Stable & 0.00 & 0.125 \\
\hline & Left & 2874.700 & 0.00 & 13.102 \\
\hline & Right & 452.463 & 0.00 & 13.102 \\
\hline & Roof & 0.000 & 0.01 & 0.125 \\
\hline \multirow{4}{*}{$\mathrm{J} 2, \mathrm{~J} 4, \mathrm{~J} 5$} & Floor & Stable & 0.00 & 0.013 \\
\hline & Left & 12264.928 & 0.00 & 13.469 \\
\hline & Right & 371.609 & 0.00 & 13.469 \\
\hline & Roof & 0.000 & 0.00 & 0.013 \\
\hline \multirow{4}{*}{$\mathrm{J} 2, \mathrm{~J} 4, \mathrm{~J} 6$} & Floor & Stable & 0.00 & 28.370 \\
\hline & Left & 574.165 & 0.00 & 0.297 \\
\hline & Right & 3024.801 & 0.00 & 0.297 \\
\hline & Roof & 0.000 & 0.04 & 28.370 \\
\hline \multirow{4}{*}{$\mathrm{J} 3, \mathrm{~J} 4, \mathrm{~J} 5$} & Floor & Stable & 0.00 & 1.288 \\
\hline & Left & 1105.018 & 0.00 & 11.379 \\
\hline & Right & 371.609 & 0.00 & 11.379 \\
\hline & Roof & 0.000 & 0.01 & 1.288 \\
\hline \multirow{4}{*}{$\mathrm{J} 3, \mathrm{~J} 4, \mathrm{~J} 6$} & Floor & Stable & 0.00 & 24.068 \\
\hline & Left & 544.096 & 0.00 & 0.625 \\
\hline & Right & 2049.625 & 0.00 & 0.625 \\
\hline & Roof & 0.000 & 0.04 & 24.068 \\
\hline
\end{tabular}

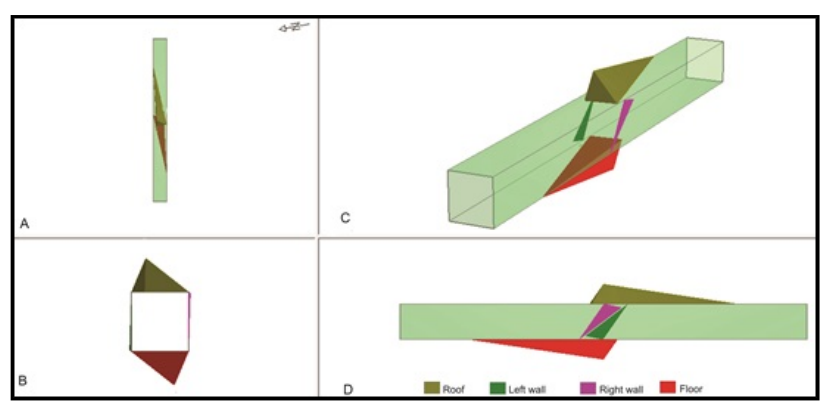

Figure 3: four views. 


\section{CONCLUSION \& RECOMMENDATION}

It can be concluded that the GSI value for Crocker Formation for this case study is 50, rock mass properties are $3.67,0.065 \mathrm{MPa}$ and $25.20^{\circ}$ of cohesion, tensile strength and friction angle, respectively, very unfavourable discontinuities combination is J2J4J6 and the support pressure required for rock bolts or shotcrete is $0.04 \mathrm{MN}$.

GSI can be a good alternative for tunnel study due to its simplicity and accuracy in estimating the rock mass properties provided with sufficient data and tools. However, the GSI should be applied in homogeneous or isotropic and not in structurally controlled rock masses.

\section{REFERENCES}

[1] Jasin, B., Tahir, S., and Tating, F. F. 1991. Late Eocene planktonic foraminifera from the Crocker Formation, Pun Batu, Sabah. Warta Geologi, 174, 187-191.

[2] Hoek, E., Wood, D., and Shah, S. 1992. A modified Hoek-Brown criterion for jointed rock masses. Proceeding Rock

Characterization, Symposium International Society of Rock Mechanics: Eurock '92. (ed. J.A. Hudson), 209-214.

[3] Hoek, E., and Brown, E. T. 1997. Practical estimates of rock mass strength. International Journal Rock Mechanics, Mining Sciences and Geomechanic Abstract, 34 (8), 1165.

[4] Bieniawski, Z. T. 1973. Engineering Classification of Jointed Rock Masses. Transaction of the South African Institution of Civil Engineering, 15 (12), 353-343.

[5] Marinos, V., Fortsakis, P., and Prountzopoulos, G. 2011. Estimation of geotechnical properties and classification of geotechnical behaviour in tunnelling for flysch rock masses. Proceeding of the $15^{\text {th }}$ European Conference on Soil Mechanics and Geotechnical Engineering, Athens. Part 1, 435-440.

[6] Marinos, P., Hoek, E., Kazilis, N., Agistalis, G. and Marinos, V. 2005. The tunnels of Egnatia highway. Design and construction in a variety of rock masses under difficult geological conditions. Proceedings of Geoline, 2005. CD.

[7] Palomba, M., Russo, G., Amadini, F., Carrieri, G., and Jain, A. R. 2013. Chenani-Nashri Tunnel, the longest road tunnel in India: a challenging case
[8] ISRM. 1978. Suggested method for quantitative description of discontinuities in rock masses. International Journal of Rock Mechanics, Mining Sciences and Geomechanic Abstracts, 15, 319-368.

[9] Marinos, V. 2007. Geotechnical classification and engineering geological behaviour of weak and complex rock masses in tunnelling. Doctoral thesis. School of Civil Engineering, Geotechnical Engineering Department, National Technical University of Athens (NTUA). Athens.

[10] Hoek, E., Caranza-Torres, C. T., and Corcum, B. 2002. Hoek-Brown failure criterion 2002 edition. In: Bawden HRW, Curran J, Telsenicki M (eds) Proceedings of the NARMS-TAC 2002. Mining Innovation and Technology, Toronto, 267-273.

[11] ISRM. 1985. Suggested method for determining point load strength. International Journal of Rock Mechanics, Mining Sciences and Geomechanics Abstracts, 22, 51-60.

[12] ISRM. 1977. SM for determining water content, porosity, density, absorption and related properties and swelling and slake-durability index properties. International Society of Rock Mechanics Suggested Method, 9294.

[13] Marinos, P., and Hoek, E. 2000. From the Geological to the Rock Mass Model: Driving the Egnatia Highway through difficult geological conditions, Northern Greece. 10th International Conference of Italian National Council of Geologists: The fragile territory, Research and application on Hydrogeological disarray in the world, forecasting-prevention-mitigation, Rome, 325-334.

[14] Rocscience Inc. 2013. ROCLAB Ver. 1.0 Software for calculating Hoek-Brown rock mass strength. Toronto, Ontario, www.rocscience.com

[15] Rocscience Inc. 2004. UNWEDGE Ver. 3.0 Underground wedge stability analysis. Toronto, Ontario, www.rocscience.com

[16] Goodman, R. E., and Shi, G. 1985. Block Theory and Its Application to Rock Engineering. Prentice-Hall Inc, Englewood Cliffs, New Jersey.

[17] Marinos, P. 2014. Personal communication.

[18] Bieniawski, Z. T. 1989. Engineering Rock Mass Classifications. Wiley, New York, 248.

[19] Hoek, E. 2014. Personal communication. 